\footnotetext{
${ }^{1}$ Faculty of Animal Bioengineering, University of Warmia and Mazury in Olsztyn, Olsztyn, Poland

${ }^{2}$ Faculty of Animal Science, Warsaw University of Life Sciences, Warsaw, Poland
}

\title{
Quality of goat meat from purebred French Alpine kids and Boer crossbreeds
}

\begin{abstract}
Some quality traits of meat from purebred French Alpine kids and Boer crossbreeds aged 50 days were evaluated in the study. Samples of $m$. quadriceps femoris were taken to determine the chemical composition and physicochemical properties of meat as well as a water-to-protein ratio, energy value, levels of cholesterol and amino acids in protein, and fatty acid concentration in intramuscular fat. It was found that meat from crossbred kids, compared to meat from purebred kids, contained more intramuscular fat, cholesterol and vitamin A, had a higher calorific value, a brighter color, a lower water-holding capacity, a higher level of physiological maturity (measured as the value of a water-to-protein ratio), and got higher scores for tenderness and juiciness. The protein of meat from crossbred kids had a more desirable essential amino acid/non-essential amino acid (EAA/NEAA) ratio, while intramuscular fat contained less OFAs and had more desirable unsaturated fatty acid/ saturated fatty acid (UFA/SFA) and DFA/OFA (UFA $+\mathrm{C}_{18: 0} / \mathrm{SFA}-\mathrm{C}_{18: 0}$ ) ratios. Due to a high protein content (19.44 and $19.74 \%$ ), low levels of fat (1.67 and $1.96 \%$ ) and cholesterol (48.76 and $56.63 \mathrm{mg} / 100 \mathrm{~g})$, a low energy value $(96.36$ and $101.47 \mathrm{kcal} / 100 \mathrm{~g})$, a high concentration of essential amino acids, a desirable fatty acid profile and high scores for sensory properties, meat from purebred French Alpine kids and (especially) Boer crossbreds may be recommended as a valuable component of a low-fat diet.
\end{abstract}

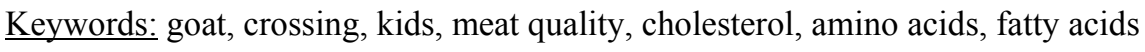

\section{Zusammenfassung}

Titel der Arbeit: Qualität des Zickleinfleisches der Französischen Alpenziege und deren Kreuzungsnachkommen mit Böcken der Burenrasse

Es wurden ausgewählte Qualitätsmerkmale des Fleisches von 50 Tage alten Zicklein der französischen Alpenziege und deren Kreuzungsnachkommen mit Böcken der Burenrasse verglichen. Bei Fleischproben aus dem M. quadriceps femoris wurden die chemische Zusammensetzung, physiochemische Eigenschaften, Wasser/Eiweißindex als Reifemaß, Energie-, Cholesteringehalt, Aminosäureprofil des Muskelfleisches und die Zusammensetzung der Fettsäuren im intramuskulären Fett bestimmt. Bei den Kreuzungstieren ergab sich gegenüber den Reinzuchttieren ein höherer Gehalt an intramuskulärem Fett, Cholesterin und Vitamin A sowie ein höherer Energiegehalt, hellere Fleischfarbe, geringere Wasserhaltekapazität, höherer physiologischer Reifegrad (Wasser/Eiweißindex), bessere Zartheit und Saftigkeit. Das Fleischeiweiß hatte ein günstigeres Verhältnis der essentiellen (EAA) zu den nicht essentiellen Aminosäuren (NEAA), wobei das intramuskuläre Fettgewebe weniger OFA (SFA-C $\mathrm{C}_{18: 0}$ ), jedoch ein besseres Verhältnis der ungesättigten (UFA) zu den gesättigten Fettsäuren (SFA) und DFA $\left(\mathrm{UFA}+\mathrm{C}_{18: 0}\right)$ zu OFA aufwies. Der höhere Eiweißgehalt (ReinzuchtKreuzung 19,44-19,74\%), relativ niedrige Fett- (1,67-1,96\%), Cholesterin- (48,76-56,63 mg/100g) und Energiegehalte, vor allem die höheren Gehalte an essentiellen Aminosäuren, ein günstiges Fettsäurenprofil und gute sensorische Eigenschaften weisen darauf hin, dass Fleisch der untersuchten Zicklein - insbesondere der Kreuzungstiere - sich als fettarme Diätkost empfiehlt.

Schlüsselwörter: Ziegen, Kreuzung, Zicklein, Fleischqualität, Cholesterin, Aminosäuren, Fettsäuren 


\section{Introduction}

The increasing interest in goat breeding and farming, observed recently in many developed countries including Poland, is related to the fact that goat products are considered a delicacy of great nutritional value (PARK, 2000; PIENIAK-LENDZION, 2001; MARICHAL et al., 2003; WALISIEWICZ-NIEDBALSKA et al., 2004; DANKOW et al., 2006). The consumption levels of animal proteins (primarily meat proteins) are higher in more affluent societies, where consumers prefer light, easily digestible and low-fat meat, recommended by dieticians as a component of a healthy diet and promoted via disease prevention programs (PFEUFFER, 2001; PIENIAKLENDZION, 2001). High-quality goat meat produced from kids characterized by high meatiness and low fatness meets the above requirements, so the demand for this kind of meat is constantly growing both in the EU member states and in the USA (LEIDNER, 1998; RINGDORFER, 2001). The meat quality traits of slaughter goat kids of dairy breeds are usually poor, since goats are selected primarily towards improving their milk performance. In order to increase the meatiness of slaughter kids, attempts are made to cross does of dairy breeds with bucks of meat breeds (RINGDORFER, 2001; DHANDA et al., 2003; STANISZ et al., 2004; SHRESTHA and FAHMY, 2007).

The aim of the present study was to determine some quality indices of meat from 50-day-old F1 crossbred male kids, produced by the mating of French Alpine does to Boer bucks.

\section{Materials and Methods}

The experiment was performed on purebred French Alpine (FA) male kids and French Alpine $\times$ Boer F1 crossbreds (FAB), aged 50 days, 12 animals per group. All kids were raised under identical husbandry, management and feeding conditions. Apart from doe's milk, the kids were fed ad libitum meadow hay and concentrate C-J for lambs and calves, as well as green forage at the last stage of the experiment, prior to slaughter. The level of nutrition has been balanced due to the feeding norms for goats (KOWALSKI, 1993).

The kids were slaughtered at 50 days of age and at mean body weight of $13.8 \mathrm{~kg}$ and $14.9 \mathrm{~kg}$ in the group of purebreds and crossbreds, respectively. Samples of $m$. quadriceps femoris were taken from chilled carcasses for meat quality evaluation. The following determinations were made: dry matter by sample drying at 105 , total protein by the Kjeldahl method, crude fat by the Soxhlet method, crude ash by ashing at 550 , gross energy value using a KL-10 adiabatic bomb calorimeter, water-holding capacity by the GRAU and HAMM method (1953), color brightness using a Specol spectrocolorimeter with a R 045 remission attachment, at a wavelength of $560 \mathrm{~mm}$, and $\mathrm{pH} 24 \mathrm{~h}$ post mortem with a Radiometer PHM $22 \mathrm{pH}$-meter. The water to protein ratio was determined based on the water and protein content of meat. Amino acid concentrations in meat protein were determined using an automatic amino acid analyzer (AAA-T-339M, MICROTECHNA). Sulfur-containing amino acids, cystine and methionine, were determined as cystinic acid and methionine sulfone. Cholesterol was measured with an EPOLL 20 colorimeter, as described by RHEE et al. (1982). The levels of vitamins A and E were determined by HPLC on a Shimadzu chromatograph, as described by RETTENMAIER and SCHÜEP (1992). The fatty acid 
composition of intramuscular fat was determined by esterification (PEISKER, 1964) followed by gas chromatography with the use of a PYE Unicam series 104 chromatograph equipped with a flame-ionization detector and a glass column $2.1 \mathrm{~m}$ in length, $4 \mathrm{~mm}$ in inner diameter (ŻEGARSKA et al., 1979). The sensory evaluation of meat samples was preceded by heat treatment, as described by BARYŁKOPIKIELNA (1975). A five-point scale was used to evaluate the following quality attributes of cooked goat meat: tenderness, juiciness, aroma (intensity and desirability) and taste (intensity and desirability). The results were verified statistically by t-test, using STATISTICA 7.1 software.

\section{Results}

Some meat quality traits (Table 1) were found to be dependent on the genotype. Meat from crossbred kids (FAB), compared to meat from purebred kids (FA), contained more intramuscular fat, cholesterol and vitamin $\mathrm{A}(\mathrm{P} \leq 0.05)$, had a higher calorific value $(\mathrm{P} \leq 0.01)$, a brighter color, a lower water-holding capacity, a lower $\mathrm{pH}(\mathrm{P} \leq 0.05)$, and a more desirable water-to-protein ratio which may indicate a higher level of physiological maturity.

Table 1

Quality traits of meat from male kids (Qualitätsmerkmale des Zickleinfleisches)

\begin{tabular}{|c|c|c|c|c|c|}
\hline \multirow{2}{*}{ Specification } & & \multicolumn{2}{|c|}{ French Alpine } & \multicolumn{2}{|c|}{ French Alpine $\propto \times$ Boer $\widehat{\jmath}$} \\
\hline & & $\overline{\mathrm{x}}$ & SD & $\overline{\mathrm{x}}$ & $\mathrm{SD}$ \\
\hline Dry matter & $(\%)$ & 22.21 & 2.42 & 23.21 & 1.97 \\
\hline Crude protein & $(\%)$ & 19.44 & 1.44 & 19.74 & 1.18 \\
\hline Fat & $(\%)$ & $1.67^{\mathrm{b}}$ & 30.05 & $1.96^{\mathrm{a}}$ & 18.44 \\
\hline Ash & $(\%)$ & 1.10 & 8.92 & 1.13 & 7.17 \\
\hline $\mathrm{pH} 24 \mathrm{~h}$ & & $5.78^{\mathrm{a}}$ & 1.36 & $5.70^{\mathrm{b}}$ & 1.41 \\
\hline Water/protein ratio & & $4.18^{\mathrm{a}}$ & 0.88 & $3.89^{\mathrm{b}}$ & 3.65 \\
\hline $\mathrm{GE} / 100 \mathrm{~g}$ & & $96.36^{\mathrm{B}}$ & 0.91 & $101.47^{\mathrm{A}}$ & 3.23 \\
\hline Color & $(\%)$ & $13.83^{\mathrm{b}}$ & 15.97 & $15.38^{\mathrm{a}}$ & 7.73 \\
\hline Water holding capacity & $\left(\mathrm{cm}^{2)}\right.$ & $7.02^{\mathrm{b}}$ & 12.52 & $8.09^{\mathrm{a}}$ & 14.71 \\
\hline Cholesterol & $\mathrm{mg} / 100 \mathrm{~g}$ & $48.76^{\mathrm{b}}$ & 28.07 & $56.63^{\mathrm{a}}$ & 21.32 \\
\hline Vitamin A & $\mathrm{mg} / 100 \mathrm{~g}$ & $5.02^{\mathrm{b}}$ & 31.55 & $7.62^{\mathrm{a}}$ & 21.83 \\
\hline Vitamin E & $\mathrm{mg} / 100 \mathrm{~g}$ & 32.42 & 31.95 & 28.82 & 41.46 \\
\hline
\end{tabular}

$\mathrm{A}, \mathrm{B}=\mathrm{P} \leq 0.01 ; \mathrm{a}, \mathrm{b}=\mathrm{P} \leq 0.05$

The genotype of kids had a significant effect on the concentrations of amino acids in meat protein (Table 2). The protein of meat from FAB kids, in comparison with the protein of meat from FA kids, contained significantly and highly significantly more EAAs such as threonine, valine, methionine, leucine and lysine, and less NEAAs, such as glutaminic acid, glycine and alanine. It follows that the proportions and ratios of EAAs and NEAAs in the protein of meat from crossbreds were more desirable than in the protein of meat from purebreds $(\mathrm{P} \leq 0.05)$.

Interbreed crossing resulted also in significant differences in the fatty acid composition of intramuscular fat (Table 3). In the group of FAB kids intramuscular fat contained significantly less SFAs, including $\mathrm{C}_{12: 0}, \mathrm{C}_{14: 0}$ and $\mathrm{C}_{18: 0}$, and significantly more $\mathrm{C}_{14: 1}$ and $\mathrm{C}_{18: 3}$ and total polyunsaturated fatty acids (PUFAs). As a result of these differences, the intramuscular fat of meat from crossbred kids contained significantly less hypercholesterolemic acids (OFAs) and had more desirable UFA : SFA and DFA : OFA ratios, compared to the intramuscular fat of meat from purebred kids $(\mathrm{P} \leq 0.05)$. 
Table 2

Amino acid profile of protein in meat from male kids (\%) (Aminosäurenprofil des Zickleinfleisches (\%)

\begin{tabular}{|c|c|c|c|c|}
\hline \multirow{2}{*}{ Amino acid } & \multicolumn{2}{|c|}{ French Alpine } & \multicolumn{2}{|c|}{ French Alpine $q \times$ Boer $\delta$} \\
\hline & $\overline{\mathrm{x}}$ & $\mathrm{SD}$ & $\overline{\mathrm{x}}$ & $\mathrm{SD}$ \\
\hline Threonine & $4.71^{\mathrm{B}}$ & 1.48 & $5.00^{\mathrm{A}}$ & 1.15 \\
\hline Valine & $5.18^{b}$ & 2.43 & $5.43^{\mathrm{a}}$ & 1.81 \\
\hline Methionine & $3.40^{\mathrm{b}}$ & 2.15 & $3.52^{\mathrm{a}}$ & 1.70 \\
\hline Isoleucine & 4.70 & 2.63 & 4.76 & 2.58 \\
\hline Leucine & $8.13^{\mathrm{b}}$ & 1.23 & $8.36^{\mathrm{a}}$ & 2.17 \\
\hline Phenylalanine & 4.54 & 1.67 & 4.47 & 6.75 \\
\hline Histidine & 3.75 & 1.85 & 3.86 & 2.02 \\
\hline Lysine & $8.58^{\mathrm{B}}$ & 2.31 & $8.88^{\mathrm{A}}$ & 1.98 \\
\hline Tryptophan & 1.23 & 2.47 & 1.24 & 4.06 \\
\hline Total EAAs & $44.22^{b}$ & 1.07 & $45.52^{a}$ & 1.45 \\
\hline Aspartic acid & 8.95 & 1.08 & 8.86 & 1.13 \\
\hline Serine & 4.03 & 1.87 & 3.96 & 1.08 \\
\hline Glutamic acid & $14.86^{\mathrm{A}}$ & 2.10 & $14.47^{\mathrm{B}}$ & 1.81 \\
\hline Proline & 3.58 & 0.87 & 3.55 & 2.28 \\
\hline Cystine & 1.18 & 1.36 & 1.16 & 2.15 \\
\hline Glycine & $4.48^{\mathrm{a}}$ & 2.55 & $4.30^{\mathrm{b}}$ & 1.32 \\
\hline Alanine & $5.43^{\mathrm{A}}$ & 2.39 & $4.95^{\mathrm{B}}$ & 2.16 \\
\hline Tyrosine & 4.41 & 2.70 & 4.31 & 1.48 \\
\hline Arginine & 5.51 & 3.90 & 5.58 & 2.19 \\
\hline Total NEAAs & $52.43^{a}$ & 0.55 & $51.15^{b}$ & 0.77 \\
\hline ESAA/NEAA & $0.84^{\mathrm{b}}$ & 1.41 & $0.89^{\mathrm{a}}$ & 1.52 \\
\hline
\end{tabular}

$\mathrm{A}, \mathrm{B}=\mathrm{P} \leq 0.01 ; \mathrm{a}, \mathrm{b}=\mathrm{P} \leq 0.05$

Table 3

Fatty acid composition in intramuscular fat (\%) (Zusammensetzung der Fettsäuren des intramuskulären Fetts [\%])

\begin{tabular}{|c|c|c|c|c|}
\hline \multirow{2}{*}{ Fatty acid } & \multicolumn{2}{|c|}{ French Alpine } & \multicolumn{2}{|c|}{ French Alpine ${ }_{+} \times$Boer $\overbrace{}^{\top}$} \\
\hline & $\overline{\mathrm{x}}$ & $\mathrm{SD}$ & $\bar{x}$ & SD \\
\hline $\mathrm{C}_{12: 0}$ & $0.87^{\mathrm{a}}$ & 12.16 & $0.74^{\mathrm{b}}$ & 29.08 \\
\hline $\mathrm{C}_{14: 0}$ & $6.42^{\mathrm{a}}$ & 14.61 & $6.10^{\mathrm{b}}$ & 17.36 \\
\hline $\mathrm{C}_{15: 0}$ & 0.81 & 21.06 & 0.86 & 14.30 \\
\hline $\mathrm{C}_{16: 0}$ & 25.96 & 4.66 & 25.75 & 5.55 \\
\hline $\mathrm{C}_{17: 0}$ & 1.20 & 8.61 & 1.16 & 10.65 \\
\hline $\mathrm{C}_{18: 0}$ & $13.81^{\mathrm{a}}$ & 8.48 & $13.34^{\mathrm{b}}$ & 8.72 \\
\hline $\mathrm{C}_{20: 0}$ & 0.19 & 30.30 & 0.19 & 31.29 \\
\hline Saturated & $49.26^{\mathrm{a}}$ & 2.65 & $48.14^{\mathrm{b}}$ & 6.25 \\
\hline $\mathrm{C}_{14: 1}$ & $0.48^{\mathrm{b}}$ & 43.79 & $0.60^{\mathrm{a}}$ & 23.01 \\
\hline $\mathrm{C}_{16: 1}$ & 4.76 & 8.89 & 4.66 & 11.42 \\
\hline $\mathrm{C}_{17: 1}$ & 1.14 & 9.98 & 1.18 & 34.80 \\
\hline $\mathrm{C}_{18: 1}$ & 36.61 & 5.99 & 37.22 & 8.65 \\
\hline $\mathrm{C}_{20: 1}$ & 0.52 & 10.53 & 0.60 & 52.14 \\
\hline Monounsaturated (MUFAs) & 43.51 & 5.1 & 44.26 & 8.07 \\
\hline $\mathrm{C}_{18: 2}$ & 5.37 & 21.43 & 5.44 & 12.25 \\
\hline $\mathrm{C}_{18: 3}$ & $0.71^{\mathrm{b}}$ & 18.53 & $0.85^{\mathrm{a}}$ & 17.23 \\
\hline $\mathrm{C}_{20: 4}$ & 1.15 & 29.78 & 1.20 & 20.63 \\
\hline Polyunsaturated & $7.23^{\mathrm{b}}$ & 22.11 & $7.49^{\mathrm{a}}$ & 20.63 \\
\hline Unsaturated & 50.74 & 2.89 & 51.75 & 7.5 \\
\hline UFA : SFA & $1.03^{\mathrm{b}}$ & 4.60 & $1.07^{\mathrm{a}}$ & 13.92 \\
\hline PUFA : MUFA & 0.17 & 27.41 & 0.17 & 11.98 \\
\hline $\mathrm{DFA}=\mathrm{UFA}+\mathrm{C}_{18: 0}$ & 64.55 & 3.31 & 65.09 & 5.42 \\
\hline $\mathrm{OFA}=\mathrm{SFA}-\mathrm{C}_{18: 0}$ & $35.45^{\mathrm{a}}$ & 5.88 & $34.80^{\mathrm{b}}$ & 7.49 \\
\hline DFA : OFA & $1.82^{\mathrm{b}}$ & 8.72 & $1.87^{\mathrm{a}}$ & 12.91 \\
\hline
\end{tabular}


The sensory evaluation confirmed good eating quality of goat meat in both groups (Table 4). Total scores for all tested meat quality attributes were 4.76 in the group of FAB kids and 4.65 in the group of FA kids. Meat from crossbreds got higher scores for tenderness and juiciness.

Table 4

Sensory evaluation of meat from male kids, scores (Sensorische Beobachtungswerte des Zickleinfleisches)

\begin{tabular}{lcr|cc}
\hline \multirow{2}{*}{ Traits } & \multicolumn{2}{c}{ French Alpine } & \multicolumn{2}{c}{ French Alpine $+\times$ Boer $\hat{\delta^{\wedge}}$} \\
\hline Aroma intensity & $\overline{\mathrm{x}}$ & $\mathrm{SD}$ & $\overline{\mathrm{x}}$ & $\mathrm{SD}$ \\
Aroma desirability & 4.83 & 1.44 & 4.92 & 1.21 \\
Tenderness & 4.92 & 1.36 & 4.92 & 1.39 \\
Juiciness & $4.25^{\mathrm{b}}$ & 11.17 & $4.46^{\mathrm{a}}$ & 9.38 \\
Taste intensity & $4.58^{\mathrm{b}}$ & 9.75 & $4.75^{\mathrm{a}}$ & 7.83 \\
Taste desirability & 4.67 & 7.94 & 4.75 & 5.37 \\
General evaluation & 4.67 & 7.94 & 4.75 & 5.37 \\
\hline
\end{tabular}

$\mathrm{a}, \mathrm{b}=\mathrm{P} \leq 0.05$

Discussion

The nutritive value of goat meat is closely related to its chemical composition, primarily to protein concentration, but also to the amount and composition of fat and to the level of the least desirable ingredient - cholesterol. Another factor that decides about the quality and nutritive value of goat meat is the genotype of animals (RINGDORFER, 2001; BESERRA et al., 2004; STANISZ et al., 2004; SIKORA and BORYS, 2006). The breed of bucks used for crossing usually affected the fat content of meat, in some cases also protein content. Boer bucks mated to French Alpine does in our study contributed to a significant increase in the intramuscular fat content of meat in the progeny. A higher fat concentration in meat from Boer crossbreds was also reported by DHANDA et al. (2003) and STANISZ et al. (2004).

Intramuscular fat impacts not only the nutritive value and sensory properties of meat, but also the dietary properties related to the level of UFAs (LEIBETSEDER, 1996; ENDER et al., 1997; OPRZĄDEK and OPRZĄDEK, 2000). In this study meat from crossbred kids had a higher intramuscular fat content and received higher scores for tenderness and juiciness. DHANDA et al., (2003) and STANISZ et al., (2004) also demonstrated that Boer bucks used for crossing contributed to an increase in the intramuscular fat content of meat in the progeny, and to an improvement in the tenderness and juiciness of meat. A higher fat concentration in the muscle fibers of crossbred kids could result in muscular tissue loosening and thus contribute to an improvement in meat palatability (DANKOWSKI and ZIELIŃSKA, 1999). Higher concentrations of intramuscular fat and hydrogen ions in meat from crossbreds could affect colour brightening and reduce water-holding capacity (OPRZAZDEK and OPRZĄDEK, 2000).

The mean $\mathrm{pH}$ values of meat from purebred (5.78) and crossbred (5.70) kids were within a range (5.5-5.9) considered optimal for high-quality goat meat (DHANDA et al., 1999; DHANDA et al., 2003; STANISZ et al., 2004). Meat from Boer crossbreds is usually characterized by a higher concentration of hydrogen ions than meat from purebreds, as observed by the above authors and confirmed in the present study.

The suitability of meat for human consumption is also determined by cholesterol content, associated with coronary heart disease. Compared to meat from other animal 
species (HASIK et al., 1999), goat meat has a low cholesterol concentration (FA kids 48.76, FBA kids - $56.63 \mathrm{mg} / 100 \mathrm{~g}$ ). SIKORA and BORYS (2006) recorded higher cholesterol levels in meat from kids slaughtered at a similar age as in our study, while BESERRA et al. (2004) observed lower cholesterol levels in much older kids (8-10 months of age). BESERRA et al. (2004) demonstrated that the cholesterol content of meat is significantly affected by goat genotypes, which was also confirmed in our experiment.

Biologically active ingredients of goat meat are also vitamins $\mathrm{A}$ and E. Vitamin A participates, among others, in protein synthesis and stimulates cell differentiation, while vitamin E prevent the oxidation of fatty acids and phospholipids and inhibits the production of nitrosamines (DAREWICZ et al., 2003). Considerable amounts of vitamins $\mathrm{A}$ and $\mathrm{E}$ in meat from goat kids indicates good nutritional value and keeping quality.

The nutritive value of meat is affected not only by the amount of protein, but also by its biological value, dependent on amino acid composition. Amino acids consumed with meat are used for the synthesis of new proteins, being key components indispensable for body growth, and participate in the biosynthesis of numerous biologically active compounds (HASIK et al., 1999, GAWECKI and HRYNIEWIECKI, 2004). Among 18 amino acids contained in meat, only a few (non-essential) are synthesized by the human body, while the other (essential for protein synthesis) must be supplied with food in the right proportions. The present results, similarly as those obtained by ELGASIM and ALKANHAL (1992), and WEBBE et al. (2005), show that the biological value of goat meat is related primarily to such essential amino acids as lysine, histidine and methionine - necessary for normal growth and development, and tryptophan and phenylalanine - regulating the functions of the central nervous system (HASIK et al., 1999). In the present experiment the protein of meat from crossbred kids had a more desirable ratio between essential and non-essential amino acids than the protein of meat from purebred kids (0.89 vs. 0.84). A comparable ratio between both groups of amino acids (0.90) in goat meat was reported by ELGASIM and ALKANHAL (1992), while a higher one was recorded by WEBB et al. (2005).

A measure of the dietary properties of meat is a ratio between saturated and unsaturated fatty acids contained in intramuscular fat. A particularly important role is played by PUFAs, being an essential and key food ingredient (LEIBESENDER, 1996; HASIK et al., 1999). Differences in the levels of individual fatty acids and total SFAs and PUFAs, observed between the two groups of male kids examined in the study, resulted in a more desirable UFA : SFA ratio in crossbreds. The concentration of essential unsaturated fatty acids is of primary importance from the perspective of a healthy diet, since they help to prevent or control hypercholesterolemia considered a key risk factor of coronary heart disease (HASIK et al., 1999; PFEUFFER, 2001). The present results show that the intramuscular fat of meat from crossbred kids contained more essential unsaturated fatty acids, compared with the intramuscular fat of meat from purebred kids (7.49\% vs. $7.23 \%)$.

The genotype of goat kids had also a considerable effect on the levels and proportions of DFAs and OFAs. Meat from crossbreds had a more desirable ratio between DFAs and OFAs. The fat of meat from crossbred kids contained more DFAs and less OFAs, and had a more desirable ratio between these acids (1.87), compared with the fat of meat from purebred kids (1.82). DFAs are believed to reduce the absorption rate of dietary cholesterol and bile acids as well as to influence lipoprotein synthesis 
(BARTNIKOWSKA 1993). A significant effect of the genotype of goat kids on the fatty acid profile of intramuscular fat was also demonstrated by KALINOWSKA and PUSTKOWIAK (2000), DHANDA et al. (2003) and BESERRA et al. (2004). Changes in the proportions of acids of different saturation degree, observed in this experiment and reported by other authors, indicate that the fatty acid profile can be modified through proper selection of goat breeds for crossing.

Due to a high protein content (19.44 and $19.74 \%)$, a desirable water-to-protein ratio (4.18 and 3.89), low levels of intramuscular fat (1.67 and $1.96 \%$ ) and cholesterol (48.76 and $56.63 \mathrm{mg} / 100 \mathrm{~g}$ ), a low energy value (96.36 and $101.47 \mathrm{kcal} / 100 \mathrm{~g}$ ), a high ratio between EAAs and NEAAs (0.84 and 0.89), a desirable fatty acid profile and high scores for sensory properties, meat from purebred French Alpine kids and (especially) French Alpine $\times$ Boer crossbreds may be recommended as a valuable component of a low-fat diet.

\section{References}

Influence of dietary fiber on lipid metabolizm in laboratory animals and humans. Acta. Acad. Agricult. Tech. Olst., Tech. Alimentorium 25 (1993), 1-101 [in Polish]

BARYŁKO-PIKIELNA, N.:

The draft of the food sensory analysis.PWN, Warszawa (1975) [in Polish]

BESERRA, F. J.; MADRUGA, M. S.; LEITE, A. M.; DA SILVA, E. M. C.; MAIA, E. L.:

Effect of age at slaughter on chemical composition of meat from Moxotó goats and their crosses. Small Rumin. Res. 55 (2004), 177-181

DANKOW, R.; PIKUL, J., WOJTOWSKI, J., CAIS-SOKOLINSKA, D.:

Effect of packing systems on the quality and shelf-life of the Rokpol type mould cheese from goat milk. Arch. Tierz. 49 (2006), Special Issue, 214-218

DANKOWSKI, A.; ZIELIŃSKA, M.: Problem of fatness in slaughter lambs, Part I. General issues Przeg. Hod. 12 (1999), 19-22 [in Polish]

DAREWICZ, M.; DZIUBA, J.; PANFIL, T.:

Biologically aetive components of functional ford in the context of cangerdiseases prefention. Żywność 4 (2003), 36-47 [in Polish]

DHANDA, J.S.; TAYLOR, D.G.; MURRAY, P.J.; MCKOSKER, J.E.:

The influence of goat genotype on the production of Capretto and Chevon carcasses. 2. Meat quality. Meat Sci. 52 (1999), 363-367

DHANDA, J.S.; TAYLOR, D.G.; MURRAY, P.J.;

Part 1. Growth, carcass and meat quality parameters of male goats; effects of genotype and liveweight at slaughter. Small Rumin. Res. 50 (2003), 57-66

ELGASIM, E.A.; ALKANHAL M.A.:

Proximate composition, amino acids and inorganic mineral content of Arabian Camel meat: comparative study. Food Chem. 45 (1992), 1-4

ENDER, K.; NEURENBERG, K.; PAPSTEIN, H.J.:

Die zwei Seiten des Fettes - eine Standortbestimming. Arch. Tierz. 40 (1997), 35-45

GAWĘCKI, J.; HRYNIEWIECKI, L.:

Human nutrition. Fundamentals of Nutritional Sciences. PWN, Tom I (2004) [in Polish]

GRAU, R.; HAMM, R.; BAUMANN, A.:

Über das Wasserbindungsvermögen des toten Säugetiermuskels. I. Mitteilung. Der Einfluß des pHWertes auf die Wasserbindung von zerkleinertem Rindermuskel. Biochem. Z. 325 (1953), 1-11

HASIK, J.; HRYNIEWIECKI, L.; GRZYMISŁAWSKI, M.:

Dietetics. Wyd. Lek. PZWL (1999) [in Polish]

KALINOWSKA, B.; PUSTKOWIAK, H.:

The fatty acid profile and cholesterol content of meat and organ sof kids fattenet to $16 \mathrm{~kg}$ [in Polish] Zesz. Nauk. ARW we Wrocławiu 399 (2000), 165-168

KOWALSKI, M.:

Feeding norms for cattle, sheep and goats. National Research Institute of Animal Production (1993), 109-119 [in Polish]

\section{LEIBESENDER, J.:}

Beeinflussung der Zusammensetzung tierischer Fette durch Fütterung. Arch. Tierz. 39 (1996), 333-345 


\section{LEIDNER, J.:}

Meat goat farming talces off. Progressive Farmer 7 (1998), 52-53

MARICHAL, A.; CASTRO, N.; CAPOWE, J.; ZAMORANO, M.J.; ARGÜELLO, A.: Effects of live weight at slaughter $(6,10$ and $25 \mathrm{~kg})$ on kid carcass meat quality. Livestock Prod. Sci. 83 (2003), 247-256

OPRZĄDEK, J.; OPRZĄDEK, A.: Factors affecting beef quality. Prz. Hod. 8 (2000), 42-45 [in Polish]

PARK, Y.W.:

Comparison of mineral and cholesterol composition of different commercial goats milk products manufactured in USA. Small Ruminant Research 37 (2000), 115-124

PFEUFFER, M.:

Physiologic effects of individual fatty AIDS in Animals and human body, with particular attention to coronary heat disease risk. Arch. Tierz. 44 (2001), 89-98

PIENIAK-LENDZION, K.:

Wartość rzeźna i jakość mięsa koziołków rasy białej uszlachetnionej. Rozprawy Naukowe, Akademia Podlaska, Siedlce 66 (2001), 1-57

RETTENMAIER, R.; SCHÜEP, W.:

Determination of vitamins A and E in liver tissue. J. Vit. Nutr. Res. 62 (1992), 312-317

RHEE, K.S.; DUTSON, T.R.; SMITH, G.C.; HOSTETLER, R.L.; RREISER, R.:

Cholesterol content of raw and cooked beef longisimuss muscles with different degrees of marbling. J. Food. Sci. 47 (1982), 716-719

RINGDORFER, F,

Einfluss von Genotyp Geschlecht und Endgewicht auf die Schlachtleistung von Ziegenkitzen. Arch. Tierz. 44 (2001) Special Issue, 385-390

SIKORA, J.; BORYS, B.:

Lipid profile of intramuscular fat in kids fattened to 60, 90 and 180 days of age. Arch. Tierz. 49 (2006) Special Issue, 193-200

SHRESTHA, J.N.B.; FAHMY, M.H.:

Breeding goats for meat production. 2. Crossbreeding and formation of composite population. Small Rumin. Res. 67 (2007), 93-112

STANISZ, M.; PIETRZAK, M.; GUT, A.:

Quality of meat of crossbred male kids with $50 \%$ and $75 \%$ share of the Boer goat breed. Zesz. Nauk. Przeg. Hod. 12 (2004) 3, 173 [in Polish]

WALISIEWICZ-NIEDBALSKA, W.; PATKOWSKA-SOKOLA, B.; BODKOWSKI, R.; ROZYCKI, K.:

The influence of linoleic acid and its isomers in goat diet on the composition of fatty acid in goat milk fat. Arch.Tierz. 47 (2004) Special Issue, 103-107

WEBBE, E.C.; CASEY, N.H.; SIMELA, L.:

Goat meat quality. Small Rumin. Res. 60 (2005), 153-166

ŻEGARSKA, Z.; MARKIEWICZ, K.; SMOCZŃSKI, S.:

Composition of fatty acid in muscle fat and depot fat of rabbit. Zesz. Nauk. ART. Olsztyn 15 (1979), 167-177 [in Polish]

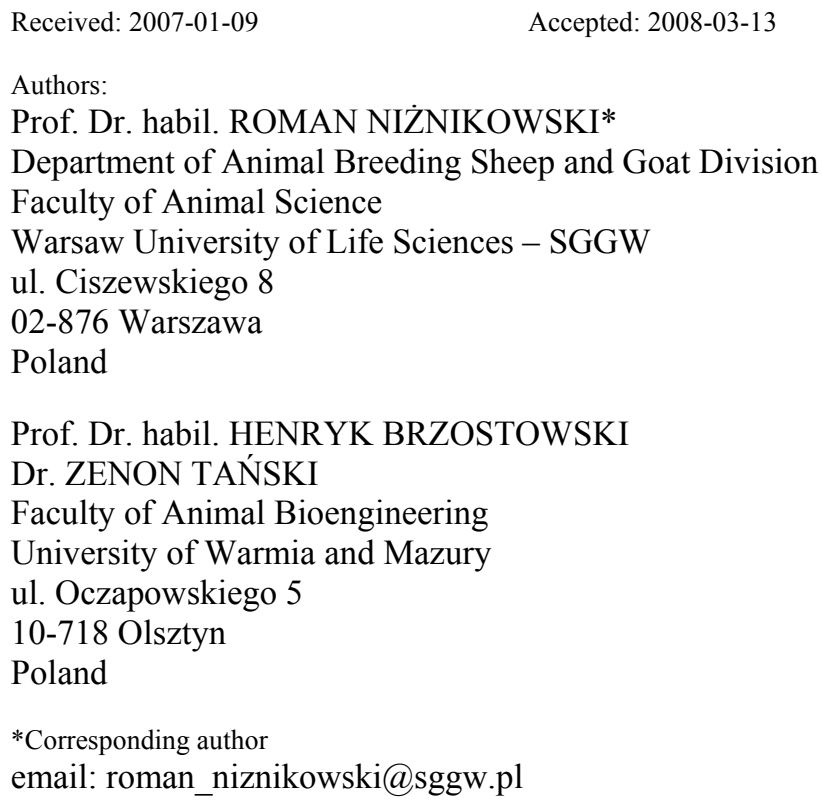

